\title{
SWAT-Based Streamflow Estimation and Its Responses to Climate Change in the Kadongjia River Watershed, Southern Tibet
}

\author{
RUI SUN \\ Institute of Geographic Sciences and Natural Resources Research, Chinese Academy of Sciences, and University \\ of Chinese Academy of Sciences, Beijing, China, Max Planck Institute for Meteorology, Hamburg, Germany \\ XUEQIN ZHANG \\ Institute of Geographic Sciences and Natural Resources Research, Chinese Academy of Sciences, Beijing, China \\ YANG SUN \\ Office of State Flood Control and Drought Relief Headquarters, Beijing, China \\ DU ZHENG \\ Institute of Geographic Sciences and Natural Resources Research, Chinese Academy of Sciences, Beijing, China

\section{KLAUS FRAEDRICH} \\ KlimaCampus, Universität Hamburg, Germany, Max Planck Institute for Meteorology, Hamburg, Germany
}

(Manuscript received 5 November 2012, in final form 15 May 2013)

\begin{abstract}
Runoff estimation and its response to climate change in ungauged or poorly gauged basins based on hydrological models are frontier research issues of the hydrological cycle. For the Kadongiia River watershed (KRW), a poorly gauged watershed located in southern Tibet, China, the Soil and Water Assessment Tool (SWAT) was adapted to model streamflow and its responses to climate change. The average annual streamflow was simulated to be roughly $124.6 \mathrm{~mm}$ with relatively small interannual variation during 19742010. The seasonal distribution of streamflow was uneven with a maximum in summer and a minimum in winter. Snowmelt, which was mainly produced in April-May, accounted for $4.0 \%$ of annual streamflow. Correlations and regression analysis between the interannual variations of major climatic and hydrological variables indicated that precipitation (temperature) had positive (negative) influence on the annual streamflow variation. For the interannual streamflow variations, warmer temperature was slightly more important than the variation of winter precipitation. Comparing streamflow changes in the current years (198099) with the future (2030-49), streamflow variations were more sensitive to changing climate in winter and spring than in the other two seasons. Model improvement is expected to enhance the simulation efficiency of SWAT and the analyses of hydrological responses to climatic change in KRW, thus supporting the model's credibility for hydrological cycle research in alpine regions.
\end{abstract}

\section{Introduction}

The Qinghai-Tibetan Plateau is the main water source for several major rivers in Asia and for large amounts of lakes, glaciers, permafrost areas, and wetlands (Shen

Corresponding author address: Xueqin Zhang, Room 3612,11A, Datun Road, Chaoyang District, Beijing 100101, China.

E-mail: zhangxq@igsnrr.ac.cn and Chen 1996; Luosang 2005). The alpine glaciers and inland lakes are key indicators of climatic change because their expansion or contraction reflects changes of water and heat balance conditions in mountainous regions (Shi and Ren 1990). With the significant warming over the plateau during the past decades (Liu and Chen 2000; Xu et al. 2003; Liu et al. 2006; Xu et al. 2008; Wang et al. 2008; You et al. 2008; Kang et al. 2010), glacier melt has been accelerating throughout almost the entire 


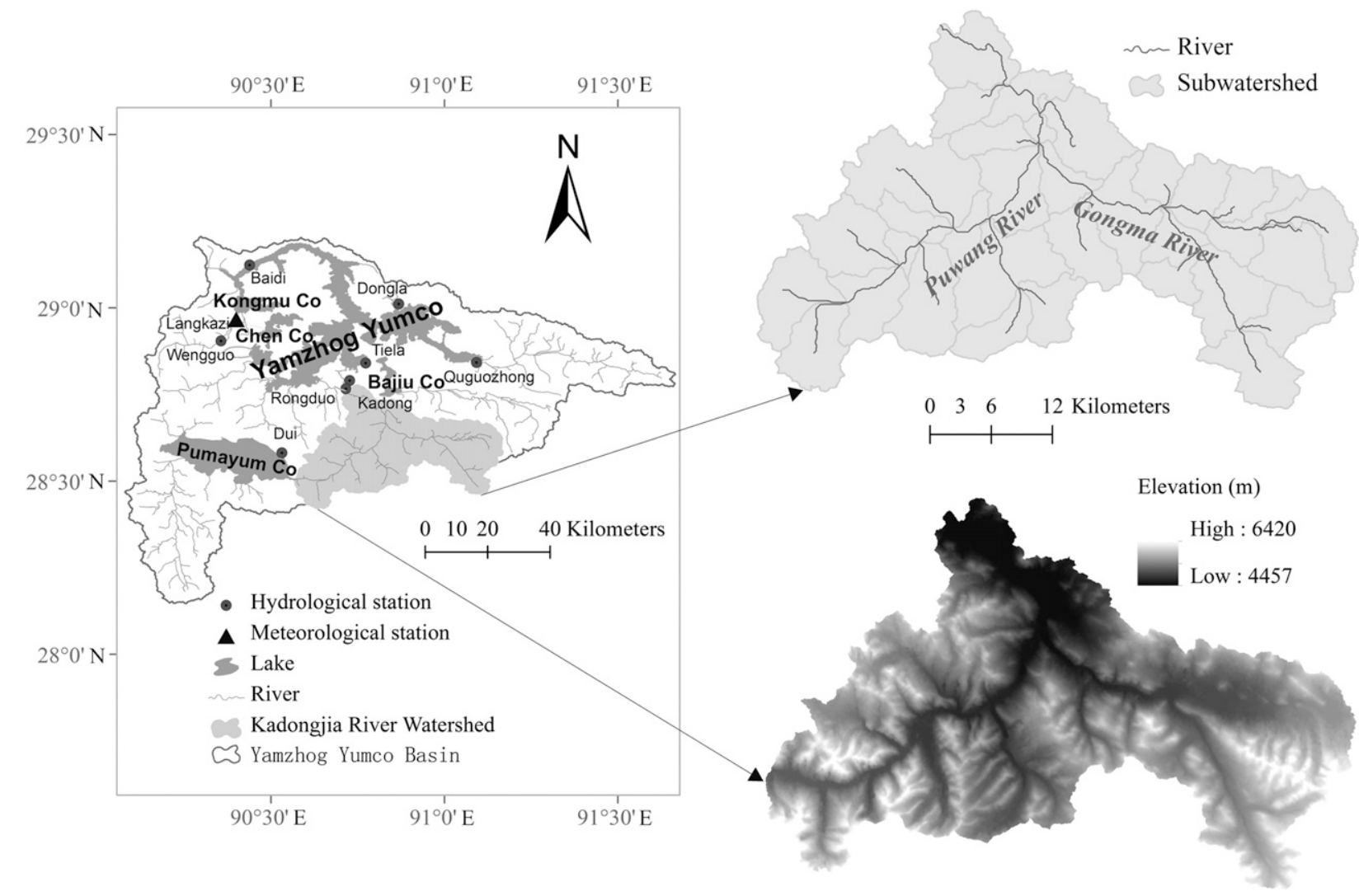

FIG. 1. The geographic position, elevation, and river network of Kadongiia River watershed and its 35 subwatersheds for SWAT modeling. The boundaries and drainage system of the watershed were extracted based on a digital elevation model (DEM) with a resolution of $30 \mathrm{~m}$ that was launched jointly by the National Aeronautics and Space Administration (NASA) and the Ministry of Economy, Trade and Industry of Japan (METI) in 2009. Additionally, the national basic topographic map with a scale of 1:100 000 published in 1974 was also used.

plateau (Chen et al. 2007; Ding et al. 2006; Kang et al. 2007; Shangguan et al. 2008; Xu et al. 2009; Yao et al. 2004; Ye et al. 2007; Wang et al. 2010; Yao et al. 2010), and some lakes supplied mainly by glacier melt have expanded as a result of increasing river inflow (Che et al. 2005; Bian et al. 2006; Shao et al. 2007; Wu and Zhu 2008; Zhu et al. 2009; Zhang et al. 2011). The temporary increase in runoff and lake level has led to flooding and devastation of grasslands and nearby villages. For other lakes supplied mainly by precipitation, however, the lake level has shrunk remarkably because of the intensified evaporation (Chen et al. 2002; Lu et al. 2005; Shao et al. 2007; Ye et al. 2007; Ye et al. 2008; Liu and Liu 2008; Qiao et al. 2010), which, eventually, will result in dwindling wetlands. Consequently, the life of local herdsmen and farmers near alpine lakes has been affected negatively by regional environmental changes. Therefore, it is urgent to analyze quantitatively the causes of alpine lake level changes.

The Yamzhog Yumco (Fig. 1), located in southern Tibet and supplied both by rainfall and snowmelt, is one of the three holy lakes in Tibet. It is the largest inland lake with an area of $588.9 \mathrm{~km}^{2}$ in the northern foot of the Himalayas (Sun et al. 2012). According to the observations at Baidi hydrological station, the lake level has dropped significantly during 1974-2010. Most of previous research focuses on qualitative analyses of the relationships between lake variations and climatic changes (Liu 1995; Bian et al. 2009; Gao et al. 2009; Chu et al. 2012a; Chu et al. 2012b; Tian et al. 2012), and the main factors for the dwindling lakes are seldom identified clearly. Hence it is of significance to explore the predominant causes for lake changes based on a balance between inflow (e.g., rainfall over lake, river inflows) and outflow (e.g., evaporation from lake). As the runoff entering the lake can influence the lake level directly, it is important to estimate the streamflow of inflowing rivers and its responses to climate change.

Because of the plateau's remoteness, high altitude, and harsh weather conditions, the quantitative estimation of river inflows and their changes are still poor in Yamzhog Yumco basin. There were once eight hydrological stations 
before the late twentieth century (Fig. 1). There is only one hydrological station (Wengguo) measuring streamflow of Kaluxiong River and two hydrological stations (Baidi and Dui) observing lake levels of Yamzhog Yumco and Pumayum Co, respectively. Constrained by the hydrological data conditions, it is important to estimate runoff based on hydrological models as suggested by the International Association of Hydrological Sciences (IAHS) Decade on Predictions in Ungauged Basins (PUB; Sivapalan et al. 2003). In practice, hydrological models need to be calibrated prior to application to closely match reality given model limitations in representing complex natural processes and conditions (Refsgaard 1997; Gupta et al. 1998; Feyen et al. 2000; Xu 2003; Wu and Johnston 2007). After model calibration based on best available data, model validation is typically carried out by comparing the simulated with the observed streamflow $(\mathrm{Wu}$ and Johnston 2007).

The Kadongjia River, the largest inflow river for Yamzhog Yumco, plays a significant role in the changes of total water supply of the lake. It drains northward, from an elevation of $6420 \mathrm{~m}$ above mean sea level (MSL) in the headwaters to $4457 \mathrm{~m} \mathrm{MSL}$ at the outlet (Fig. 1). The upstream river flow is derived from two rivers (the Gongma and Puwang Rivers) originating from Xuejianqingri Snow Mountain and Mengdagangri Snow Mountain, respectively. Kadongiia River feeds the lake all year around due to the continuous supply of snowmelt water (Guan et al. 1984). The $1149.2 \mathrm{~km}^{2}$ watershed of the Kadongjia River accounts for nearly $13.1 \%$ of the $8744.7 \mathrm{~km}^{2}$ Yamzhog Yumco basin. It extends $58.9 \mathrm{~km}$ in the east-west direction and $39.1 \mathrm{~km}$ in the north-south direction. Taking into account the sparse hydrological and meteorological data of the Kadongjia River watershed (KRW), the Soil and Water Assessment Tool (SWAT) is applied to estimate the streamflow of the Kadongjia River and its responses to climate change during 1974-2010 and then to project future streamflow changes under different climatic scenarios, which will provide more hydrological information and theoretical foundations for the ungauged basins in the alpine region.

\section{Method and data}

\section{a. SWAT model}

The Soil and Water Assessment Tool (SWAT), a river watershed-scale model developed by the United States Department of Agriculture (USDA; Arnold et al. 1998; Neitsch et al. 2001), is an effective tool to model streamflow in a variety of watersheds over long periods of time (e.g., Srinivasan et al. 1998; Arnold et al. 1999;
Bouraoui et al. 2005; Zhang et al. 2008; Jürgen et al. 2008; Lu et al. 2009; Pisinaras et al. 2010; Bosch et al. 2011). SWAT includes a provision for estimating runoff from frozen soil, which is defined if the temperature in the first soil layer is less than $0^{\circ} \mathrm{C}$. The runoff of frozen soils is larger than that of other soils although the model still allows significant infiltration when the frozen soils are dry (Neitsch et al. 2005). With the improved snow melting algorithm (Fontaine et al. 2002), the streamflow of alpine regions could be successfully simulated by SWAT.

The model inputs include topography, vegetation type, soil properties, and weather/climate in study watershed. The KRW is divided into 35 subwatersheds according to topography (Fig. 1). On the basis of $10 \%$ and $20 \%$ thresholds of land use and soils, respectively, each subwatershed is then further subdivided into several hydrological response units (HRUs). A total of 252 HRUs are created for the whole watershed. For each HRU, hydrological components in water budget including daily precipitation, evapotranspiration (ET), surface runoff, lateral flow, return flow, and soil moisture change are calculated.

The main settings selected in the streamflow simulations are summarized as follows. As the primary mechanism of surface and soil water loss at HRU, the potential ET was estimated by the Penman-Monteith method based on the observed daily temperature, relative humidity, solar radiation, and wind speed. The method developed by Ritchie (1972) was used to calculate actual ET. Surface runoff was estimated by the Soil Conservation Service (SCS) curve number $(\mathrm{CN})$ method based on the daily precipitation. A kinematic storage model was utilized to predict lateral flow, whereas the return flow was simulated by creating a shallow aquifer. The variable storage model method was selected for channel flood routing. Furthermore, snowmelt is controlled by the air and snowpack temperature, snow melting rate, and snow area coverage. Also, the melted snow is treated the same as rainfall for estimating runoff and percolation (Neitsch et al. 2005).

SWAT's strength in evaluating the long-term impact of climate changes on streamflow (e.g., Stonefelt et al. 2000; Fontaine et al. 2001; Chaplot 2007; Zhang et al. 2007; Ficklin et al. 2009) makes it particularly suitable for this study. For the model, climate is the external forcing of hydrological cycle, and the daily hydrological variables respond mainly to the climate variables of the same day. Streamflow is regulated by soil water change that links to two temperature-related hydrological variables (i.e., evapotranspiration and snowmelt); the response of streamflow to temperature increase depends on the relationships between the interannual variations of temperature and evapotranspiration and snowmelt. 


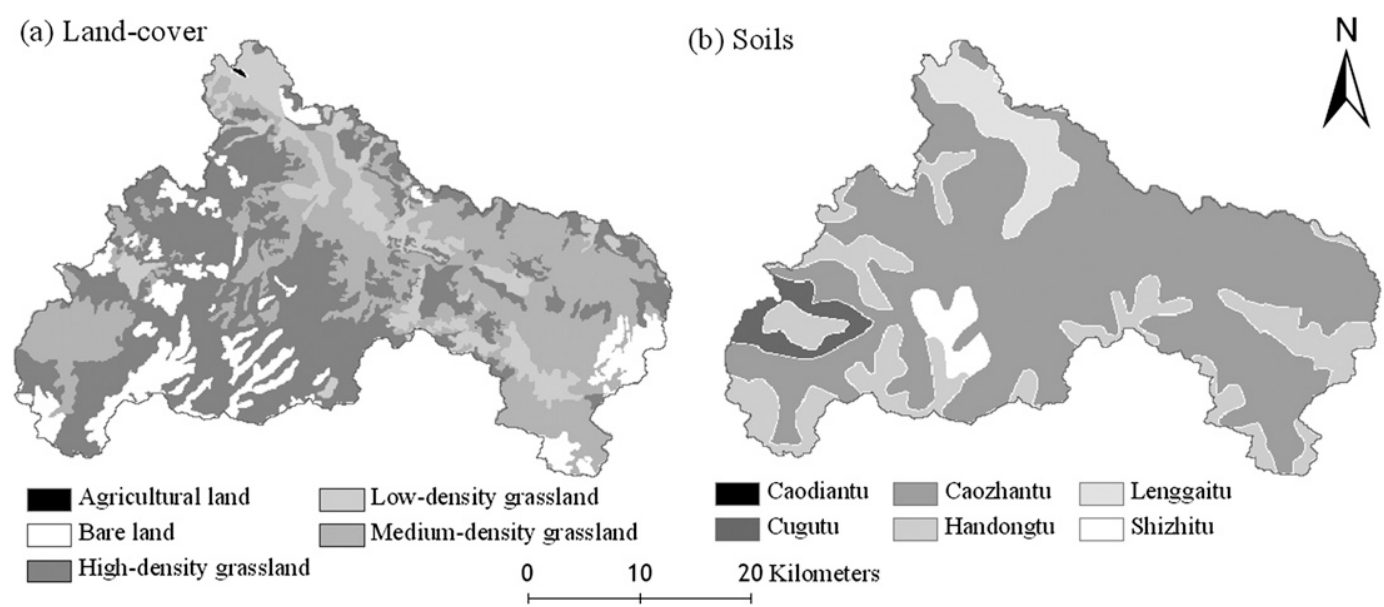

FIG. 2. (a) Vegetation distribution and (b) soil types in Kadongjia River watershed.

Hence, the influences of climate changes on SWATbased streamflow associated with evapotranspiration and snowmelt of the watershed will be discussed in section 3 .

\section{b. Data}

Data required in this study include the digital elevation model (DEM), vegetation cover, soil properties, weather and climate, and observed discharge of the KRW.

\section{1) Digital Elevation MODEL}

The DEM of the watershed was derived from the Advanced Spaceborne Thermal Emission and Reflection Radiometer (ASTER) global digital elevation model at the resolution of $30 \mathrm{~m}$. The data were downloaded from the website of the Jet Propulsion Laboratory (http:// asterweb.jpl.nasa.gov/) and processed with ArcGIS software v. 9.2 (ESRI, Redlands, California, 2006).

\section{2) Vegetation AND LAND-COVER DATA}

The land use change was too small to be considered in the sparsely populated KRW with low land use intensity during 1974-2010, for which the land-cover data of the year 2000 were used in SWAT. According to the survey completed in 2000 by Chinese Academy of Sciences (CAS), the land use and land cover in the KRW can be categorized into agricultural land $(0.07 \%)$, bare land $(10.36 \%)$, and grassland $(89.57 \%)$. The grassland was further subdivided into three types of high, medium, and low density with grass coverage over $50 \%$ of land surface, approximately $20 \%-50 \%$, and less than $20 \%$, respectively, which cover $43.11 \%, 35.33 \%$, and $11.13 \%$ of the watershed area. The spatial distributions of these land covers at the resolution of 1:100,000 are shown in Fig. 2a.

\section{3) SOILS}

Soil data at the resolution of 1:1 000000 obtained from the Data Center for Resources and Environment Science, Chinese Academy of Sciences (RESDC; http:// www.resdc.cn/first.asp) was derived from a soil survey completed in 1995 by the National Soil Survey Office of China. Six types of soils based on the Genetic Soil Classification of China are listed in Table 1. These soil types and their percentage distributions in the watershed are as follows: Caozhantu (68.71\%), Handongtu (19.13\%), Lenggaitu (6.28\%), Cugutu (3.28\%), Shizhitu $(2.55 \%)$, and Caodiantu (0.02\%) (Fig. 2b). Table 1 demonstrates the composition of each soil type and its hydrological properties, which are used to define the basin soils in the SWAT model. The compositions are based on the book Soil Species of China (National Soil Survey Office 1996). The properties were calculated by the soil-plant-atmosphere-water model SPAW (Saxton et al. 1986; Saxton and Willey 2005), developed by the USDA.

\section{4) Meteorological observation And CLIMATE SCENARIO}

Observed meteorological data were provided by China Meteorological Data Sharing Service System (http://cdc.cma.gov.cn). 1) Observations were interpolated to the DEM grids using the SWAT model's built-in weather generator to describe weather conditions in model simulations (Neitsch et al. 2002). They include daily values of maximum and minimum temperature, total precipitation, mean wind speed, and mean relative humidity for five weather stations [i.e., Zedang $\left(29.25^{\circ} \mathrm{N}\right.$, $91.77^{\circ} \mathrm{E}$, at $\left.3551.7 \mathrm{~m} \mathrm{MSL}\right)$, Jiangzi $\left(28.92^{\circ} \mathrm{N}, 89.60^{\circ} \mathrm{E}\right.$, at $4040.0 \mathrm{~m} \mathrm{MSL})$, Longzi $\left(28.42^{\circ} \mathrm{N}, 92.47^{\circ} \mathrm{E}\right.$, at $3860.0 \mathrm{~m}$ MSL), Nimu $\left(29.43^{\circ} \mathrm{N}, 90.17^{\circ} \mathrm{E}\right.$, at $\left.3809.4 \mathrm{~m} \mathrm{MSL}\right)$, and 
TABLE 1. Soil types and hydraulic properties in Kadongjia River watershed.

\begin{tabular}{|c|c|c|c|c|c|c|c|c|}
\hline \multirow{2}{*}{$\begin{array}{l}\text { Genetic soil } \\
\text { classification } \\
\text { of China }\end{array}$} & \multirow{2}{*}{$\begin{array}{l}\text { Depth of soil } \\
\text { layer }(\mathrm{mm})\end{array}$} & \multicolumn{4}{|c|}{ Composition } & \multirow{2}{*}{$\begin{array}{l}\text { Bulk density } \\
\qquad\left(\mathrm{g} \mathrm{cm}^{-3}\right)\end{array}$} & \multirow{2}{*}{$\begin{array}{c}\text { Available water } \\
\text { capacity } \\
\left(\mathrm{mm} \mathrm{mm}^{-1}\right)\end{array}$} & \multirow{2}{*}{$\begin{array}{l}\text { Saturated hydraulic } \\
\text { conductivity } \\
\left(10^{-6} \mathrm{~m} \mathrm{~s}^{-1}\right)\end{array}$} \\
\hline & & Clay (\%) & Silt (\%) & Sand $(\%)$ & Rock (\%) & & & \\
\hline \multirow{3}{*}{ Caozhantu } & $0-16$ & 6.2 & 12.0 & 81.8 & 54 & 1.44 & 0.06 & 25.3 \\
\hline & $16-30$ & 23.2 & 22.1 & 54.7 & 49 & 1.48 & 0.11 & 3.7 \\
\hline & $30-51$ & 14.5 & 2.7 & 82.8 & 79 & 1.51 & 0.06 & 11.3 \\
\hline \multirow[t]{4}{*}{ Handongtu } & $0-5$ & 12.7 & 14.0 & 73.3 & 25 & 1.48 & 0.08 & 12.1 \\
\hline & $5-20$ & 13.7 & 11.5 & 74.8 & 38 & 1.48 & 0.08 & 12.3 \\
\hline & $20-34$ & 15.5 & 10.6 & 73.9 & 38 & 1.50 & 0.08 & 9.2 \\
\hline & $34-55$ & 14.6 & 9.2 & 76.2 & 60 & 1.50 & 0.07 & 10.4 \\
\hline \multirow[t]{4}{*}{ Lenggaitu } & $0-12$ & 13.0 & 22.0 & 65.0 & 10 & 1.47 & 0.10 & 10.8 \\
\hline & $12-21$ & 14.0 & 23.0 & 63.0 & 10 & 1.47 & 0.10 & 9.6 \\
\hline & $21-55$ & 15.0 & 19.0 & 66.0 & 15 & 1.48 & 0.09 & 9.2 \\
\hline & $55-84$ & 15.0 & 22.0 & 63.0 & 30 & 1.48 & 0.10 & 8.8 \\
\hline \multirow[t]{3}{*}{ Caodiantu } & $0-26$ & 15.9 & 17.2 & 66.9 & 10 & 1.49 & 0.09 & 8.5 \\
\hline & $26-59$ & 22.3 & 42.1 & 35.6 & 10 & 1.42 & 0.15 & 3.5 \\
\hline & 59-100 & 3.5 & 39.5 & 57.0 & 10 & 1.43 & 0.12 & 20.1 \\
\hline \multirow[t]{2}{*}{ Cugutu } & $0-11$ & 25.5 & 27.3 & 47.6 & 5 & 1.46 & 0.12 & 3.0 \\
\hline & $11-39$ & 27.5 & 28.6 & 44.0 & 26 & 1.45 & 0.13 & 2.4 \\
\hline Shizhitu & $0-8$ & 15.9 & 24.8 & 59.3 & 41 & 1.47 & 0.11 & 7.6 \\
\hline
\end{tabular}

Cona $\left(27.98^{\circ} \mathrm{N}, 91.95^{\circ} \mathrm{E}\right.$, at $\left.\left.4280.3 \mathrm{~m} \mathrm{MSL}\right)\right]$ surrounding the watershed, and daily total solar radiation of Lhasa weather station $\left(29.67^{\circ} \mathrm{N}, 91.13^{\circ} \mathrm{E}\right.$, at $\left.\left.3648.9 \mathrm{~m} \mathrm{MSL}\right) .2\right)$ Observations of annual mean temperature and precipitation during 1983-95 and 2009-10 from three hydrological stations of Baidi (at $4448 \mathrm{~m}$ MSL), Wengguo (at $4590 \mathrm{~m} \mathrm{MSL}$ ), and Dui (at $5095 \mathrm{~m} \mathrm{MSL)} \mathrm{(Fig.} \mathrm{1)} \mathrm{were}$ used to calculate the vertical gradients of temperature and precipitation for the streamflow simulation based on SWAT model in KRW. Observations of monthly mean temperature and precipitation from Langkazi weather station, located near KRW, were utilized to explore the relationships between the interannual variations of hydrological and climatic variables in the watershed during 1974-2010.

Two types of climate scenarios with respect to temperature and precipitation are selected for SWAT simulations to explore the future streamflow variation of Kadongjia River. The first type is the projected climate scenario based on the dynamically downscaling results driven by modeling outputs from a global climate model, the National Center for Atmospheric Research (NCAR) Community Climate System Model, version 3 (CCSM3; Collins et al. 2006), for the A1B scenario (Nakicenovic et al. 2000). With the Eulerian-spectral dynamical core at T85 $\left(1.4^{\circ} \times 1.4^{\circ}\right)$ resolution, the simulation was performed using the G2002 physically based downscaling method (Ghan and Shippert 2006). The downscaling results at a 10 -min resolution were used to further analyze climatic changes on the Qinghai-Tibetan Plateau (Liu et al. 2009). Compared to the period of 1980-99, the monthly precipitation of Tibet in the period of 2030-49 is expected to increase by $1.89 \%$ in spring and by $2.59 \%$ in summer and to decrease by $4.42 \%$ in autumn and by $0.32 \%$ in winter; the monthly temperature of Tibet in spring, summer, autumn, and winter will increase by $1.65^{\circ}, 1.76^{\circ}, 1.96^{\circ}$, and $2.01^{\circ} \mathrm{C}$, respectively. The second type is the presumptive scenario adopted because of the large uncertainty in the projections of future anthropogenic climate change (Xu et al. 2003; Ding et al. 2007; Liu et al. 2009). Compared to the period of 1980-99, the projected monthly temperature is assumed to increase by $0^{\circ}-4^{\circ} \mathrm{C}(\Delta T)$ and the precipitation is assumed to change by $0, \pm 5 \%$, and $\pm 10 \%(\Delta P)$, respectively.

\section{5) StREAMFlow OBSERVATION}

The daily streamflow observations from the nearby two hydrologic stations (i.e., Rongduo and Kadong; Fig. 1) were collected for model calibration and validation comparing the daily simulated streamflows. The data were available from 1983 to 1995 because hydrological observations in the two stations have been stopped since 1996. With a Global Water flow probe FP101 (Global Water, Inc., Gold River, Colorado, 2004), the streamflow was also measured in a field experiment during summer 2009 and 2010 to verify the simulation results.

\section{c. Regression analysis}

To understand the relative importance of temperature and precipitation in the streamflow variations, the line regression (Ezekiel and Fox 1959) between interannual variations of hydrological and climatic variables was analyzed using the software of SPSS 13.0 for Windows 
TABLE 2. The key hydrological parameters of SWAT model adopted for the simulation of streamflow in Kadongjia River watershed.

\begin{tabular}{|c|c|c|c|c|}
\hline Parameters & Parameter description & Range & Default value & Value \\
\hline SFTMP & Snowfall temperature $\left({ }^{\circ} \mathrm{C}\right)$ & -5 to 5 & 1 & 1 \\
\hline SMTMP & Snowmelt base temperature $\left({ }^{\circ} \mathrm{C}\right)$ & -5 to 5 & 0.5 & 0 \\
\hline SMFMX & Melt factor for snow on June $21\left(\mathrm{~mm}\left({ }^{\circ} \mathrm{C} \text { day }\right)^{-1}\right)$ & $0-10$ & 4.5 & 6.5 \\
\hline SMFMN & Melt factor for snow on December $21\left(\mathrm{~mm}\left({ }^{\circ} \mathrm{C} \text { day }\right)^{-1}\right)$ & $0-10$ & 4.5 & 4 \\
\hline TIMP & Snowpack temperature lag factor & $0-1$ & 1 & 0.5 \\
\hline SNOCOVMX & $\begin{array}{l}\text { Minimum snow water content that corresponds to } 100 \% \\
\text { snow cover }(\mathrm{mm})\end{array}$ & $0-500$ & 1 & 300 \\
\hline SNO50COV & $\begin{array}{l}\text { Fraction of snow volume represented by SNOCOVMX } \\
\text { that corresponds to } 50 \% \text { snow cover }\end{array}$ & $0-1$ & 0.5 & 0.5 \\
\hline TLAPS & Vertical gradient of temperature $\left({ }^{\circ} \mathrm{C} \mathrm{km}^{-1}\right)$ & -50 to 50 & 0 & -6.6 \\
\hline PLAPS & Vertical gradient of precipitation $\left(\mathrm{mm} \mathrm{km}^{-1}\right)$ & -100 to 100 & 0 & -62.6 \\
\hline GWQMN & $\begin{array}{l}\text { Threshold depth of water in the shallow aquifer required } \\
\text { for return flow to occur }(\mathrm{mm})\end{array}$ & $0-5000$ & 0 & 0 \\
\hline REVAPMN & $\begin{array}{l}\text { Threshold depth of water in the shallow aquifer for "revap" } \\
\text { or percolation to the deep aquifer to occur }(\mathrm{mm})\end{array}$ & $0-500$ & 1 & 1 \\
\hline
\end{tabular}

(SPSS, Inc., Chicago, Illinois, 2004). Specifically, the climatic variable entry criterion was set to 0.05 and the variable retention criterion to 0.1 to minimize the discrepancies as a result of noncomparable parameters.

Assuming each monthly averaged hydrological variable $S$ to be only a function of monthly temperature $T$ and precipitation $P$, it can be expressed as $S=S(T, P)$. Then the change of $S(\Delta S)$ due to the changes of $T(\Delta T)$ and $P(\Delta P)$ can be described as

$$
\Delta S=(\partial S / \partial T) \Delta T+(\partial S / \partial P) \Delta P .
$$

If $S$ mainly varies with $T$ or $P$, the relationship can be expressed as $S=S(T)$ or $S=S(P)$. Then the corresponding change of $S$ will be

$$
\Delta S=(d S / d T) \Delta T
$$

and

$$
\Delta S=(d S / d P) \Delta P .
$$

For hydrological analysis the interaction between temperature and precipitation is neglected; that is, temperature and precipitation are assumed to be independent variables although they may be linked through atmospheric processes. Hence $d S / d T$ and $d S / d P$ in (2) and (3) and $\partial S / \partial T$ and $\partial S / \partial P$ in (1) can be approximated as the coefficients of simple regressions and multiple regression, respectively. These regression coefficients of $S$ against $T$ and $P$ represent change rates of the hydrological variable with respect to a unit increase of temperature or precipitation and reveal what is the major factor determining the change of hydrological variables as influenced by climate change. Thus, the magnitude of the interannual variability of $S$ induced by the interannual variability of $T$ and interannual variability of $P$ can be roughly evaluated with $|\partial S / \partial T| \mathrm{SD}(T)$ and $|\partial S / \partial P| \mathrm{SD}(P)$, where SD $(T)$ and SD $(P)$ are standard deviations of $T$ and $P$, respectively (Lu et al. 2009).

\section{Results}

\section{a. Model calibration and validation}

SWAT needs to be calibrated and validated with the aim to evaluate its applicability in KRW. Taking into account the continuity of meteorological and hydrological data, the model was calibrated with the observed daily streamflow dataset during 1983-90 using 1979-82 as spinup years. Then the dataset of 1991-95 was used to validate the model.

Considering the watershed located in an alpine region, some parameters related to snowfall and snowmelt were calculated for the calibration, such as elevation bands parameters, vertical gradients of temperature (TLAPS) and precipitation (PLAPS), snowfall temperature (SFTMP), snowmelt base temperature (SMTMP), and snowpack temperature lag factor (TIMP) (Table 2). SWAT allows one subwatershed to be split into a maximum of 10 elevation bands. Here all subwatersheds were divided into five elevation bands (i.e., 4400-4800, 4800-5200, 5200-5600, 5600-6000, and 6000-6500 m MSL). The TLAPS and PLAPS of KRW were $-6.6^{\circ} \mathrm{C}(\mathrm{km})^{-1}$ and $-62.6 \mathrm{~mm}(\mathrm{~km})^{-1}$. Other parameters related to snowfall and snowmelt were referred from the SWAT-based streamflow simulation in the source region of the Yellow River in the Qinghai province of China (Zhang et al. 2008). In addition, two sensitive parameters for the SWAT simulation-Gwqmn (the threshold depth of water in the shallow aquifer required for return flow to occur) and Revapmn (the threshold depth of water in the 

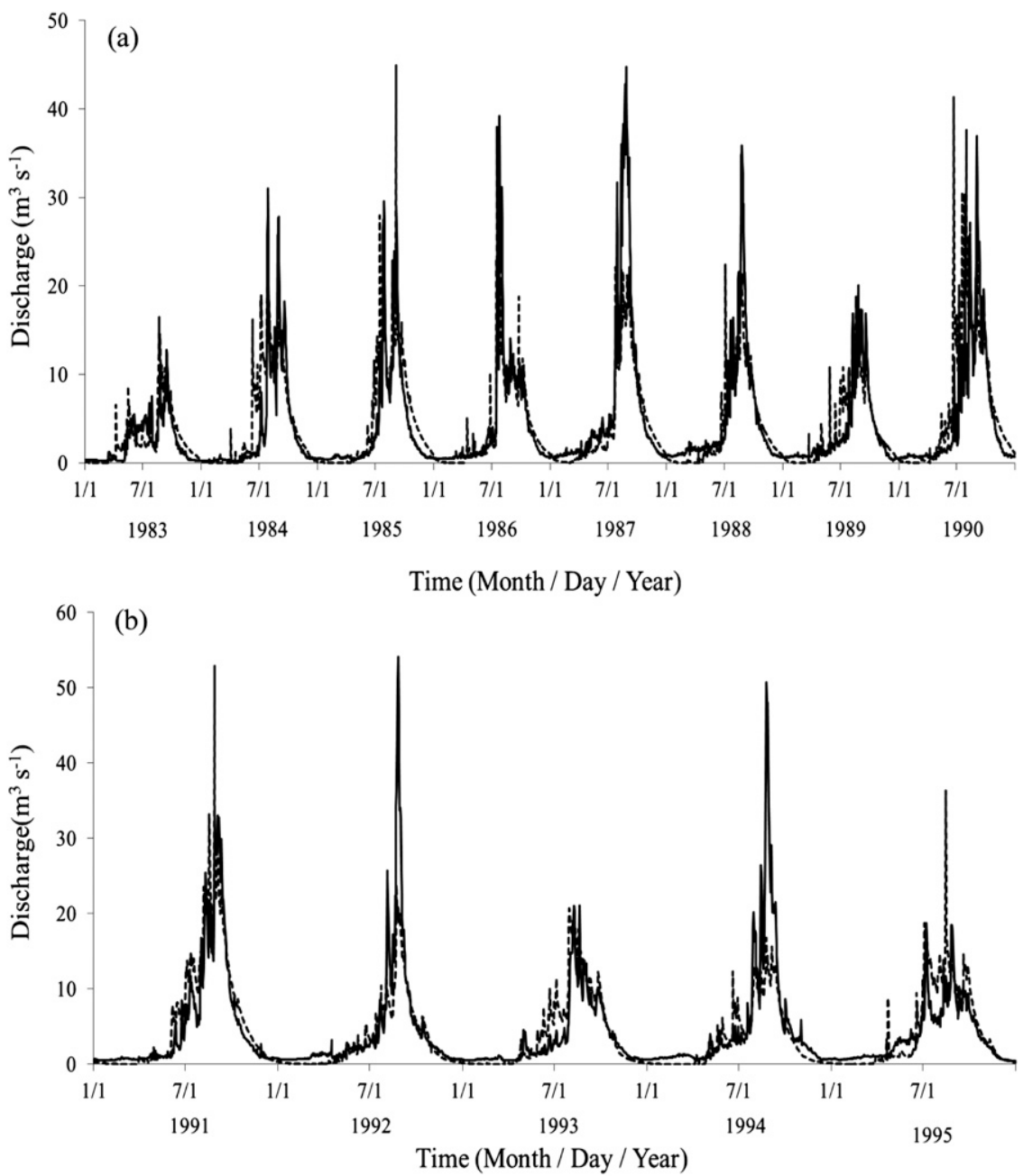

FIG. 3. Observed (solid line) and model simulated streamflow (dotted line) of Kadongjia River watershed for (a) the calibration period of 1983-90 and (b) the validation period of 1991-95.

shallow aquifer for "revap" or percolation to the deep aquifer to occur)-were adopted as the default values (Table 2) because of the good calibration results, which can be attributed to the uncalibrated SWAT providing satisfactory predictions on hydrologic budget by using accurate spatial input data (Srinivasan et al. 2010).

The calibration result is shown in Fig. 3a (dotted line), along with the observed daily streamflow (solid line) at Rongduo and Kadong hydrological stations. Besides the graphic comparison of the simulated daily streamflow with the observed (Fig. 3), three quantitative statistics were adopted to evaluate the modeling results: the bias of discharge ( $\mathrm{Re})$, the coefficient of determination $\left(R^{2}\right)$, and the Nash-Suttcliffe coefficient (Ens) (Santhi et al. 2001; White and Chaubey 2005; Moriasi et al. 2007). In general, model simulations can be judged as satisfactory if $|\operatorname{Re}| \leq 15 \%, R^{2}>0.6$, and Ens $>0.5$ for monthly streamflow. For the calibration period of 198390, the values of $\mathrm{Re}, R^{2}$, and Ens of simulated and observed daily streamflow were $1.52 \%, 0.69$, and 0.69 , respectively. Major discrepancies between modeled and observed streamflow occurred not only in the annual peaks but also in the annual minima of discharge during 1983-90 (Fig. 3a). In particular, the model underestimated discharge peaks in 1987 and 1988. But, except for these underestimations, the model depicted the hydrograph with reasonably high accuracy.

The validation result from 1991 to 1995 is shown in Fig. $3 b$ (dotted line). On the basis of comparisons between the modeled and observed daily streamflow (solid line), the values of Re, $R^{2}$, and Ens were $-3.74 \%, 0.68$, and 0.68 , respectively. Compared to the calibration period, this slight decrease of the accuracy was reflected primarily in modeled smaller discharge peaks in 1992 

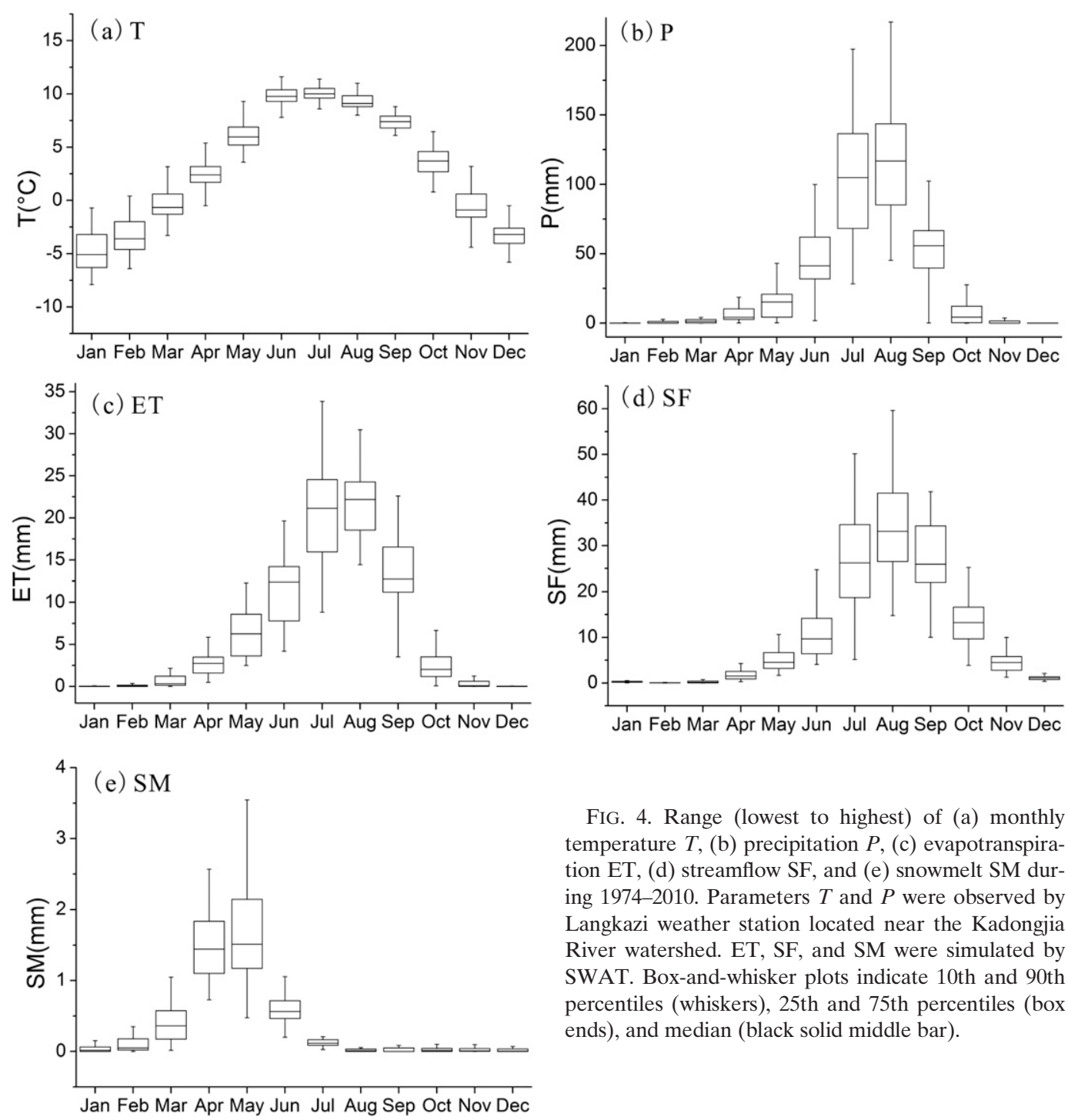

FIG. 4. Range (lowest to highest) of (a) monthly temperature $T$, (b) precipitation $P$, (c) evapotranspiration ET, (d) streamflow SF, and (e) snowmelt SM during 1974-2010. Parameters $T$ and $P$ were observed by Langkazi weather station located near the Kadongjia River watershed. ET, SF, and SM were simulated by SWAT. Box-and-whisker plots indicate 10th and 90th percentiles (whiskers), 25th and 75th percentiles (box ends), and median (black solid middle bar).

and 1994. Nonetheless, given the spatial resolutions of available data in the watershed, the low $|\operatorname{Re}|$ and high $R^{2}$ and Ens values in calibration and validation suggested that the calibrated model can describe the watershed streamflow with fairly high accuracy during 1983-95. These results indicated that the calibrated model can be applied to estimate the streamflow and its responses to climate change in the watershed.

\section{b. Variability of climate and streamflow}

The watershed lies in the alpine region with cold temperature. According to the observations of Langkazi weather station, the average annual mean temperature (T) was $3.1^{\circ} \mathrm{C}$ with the maximum in July $\left(\right.$ mean $\left.=10.1^{\circ} \mathrm{C}\right)$ and the minimum in January $\left(\right.$ mean $\left.=-4.6^{\circ} \mathrm{C}\right)$. The mean temperature was over $0^{\circ} \mathrm{C}$ from April through October, and was below the freezing point for the rest five months (Fig. 4a). The annual mean temperature had been increasing with a linear rate of $0.4^{\circ} \mathrm{C}$ decade $^{-1}$ during 1974 2010. The increases of seasonal mean temperature in winter $\left(0.6^{\circ} \mathrm{C} \mathrm{decade}{ }^{-1}\right)$ and spring $\left(0.4^{\circ} \mathrm{C} \mathrm{decade}{ }^{-1}\right)$ were much larger than in summer and autumn $\left(0.3^{\circ} \mathrm{C} \mathrm{decade}^{-1}\right)$ in the same period.

The annual precipitation $(P)$ observed between 1974 and 2010 ranged from 150.7 to $552.6 \mathrm{~mm}$ with considerable spatial and temporal distribution. The average annual precipitation was $362.0 \mathrm{~mm}$ with the maximum in summer and the minimum in winter (Fig. 4b). Also, 7.6\%, $73.7 \%, 18.2 \%$, and $0.5 \%$ of the annual precipitation occurred in spring, summer, autumn, and winter, respectively. The seasonal variation of evapotranspiration corresponded well with that of precipitation (Fig. 4c). Relative to the 


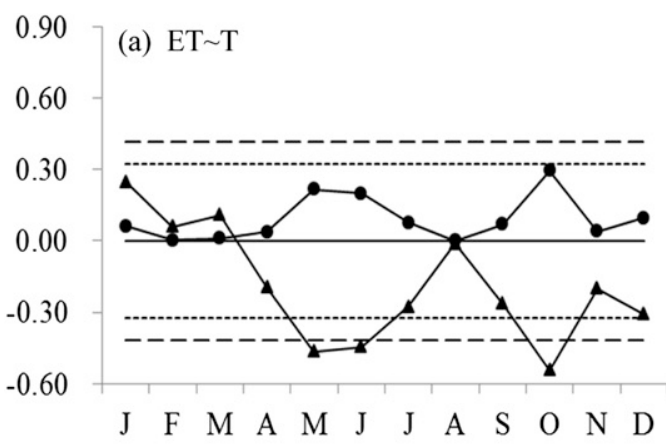

0.90

(c) $\mathrm{SM} \sim \mathrm{T}$

0.60

0.30

0.00

$-0.30$

$-0.60$

$\begin{array}{llllllllllll}\text { J } & F & M & A & M & J & J & A & \text { S } & \text { O } & \text { N } & \text { D }\end{array}$
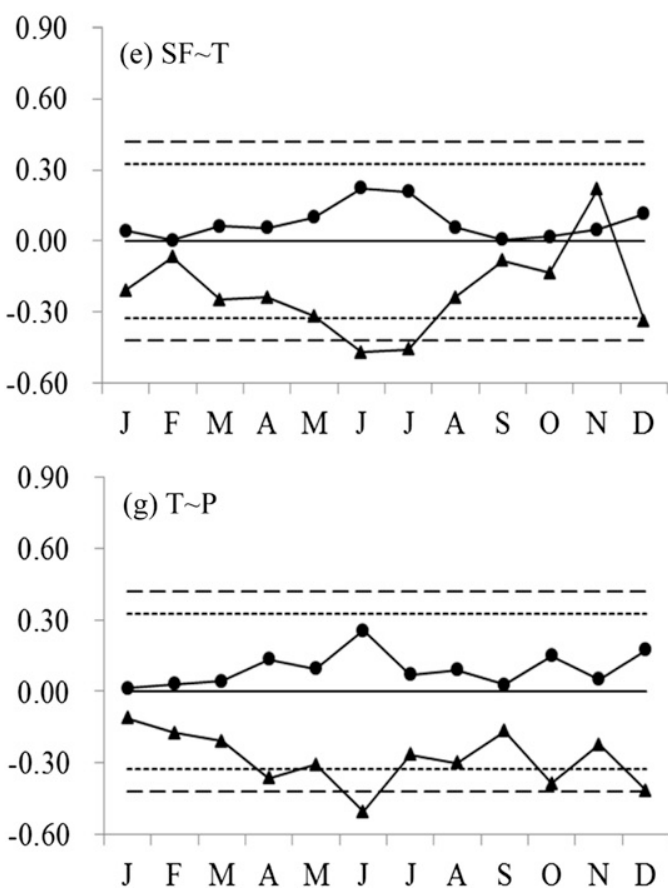

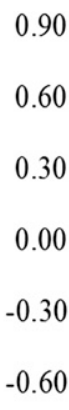

(b) ET $\sim \mathrm{P}$

0.60

0.30

0.00

$-0.30$

$-0.60$

0.90

0.60

0.30

0.00

$-0.30$

$-0.60$

0.90

0.60

0.30

0.00

$-0.30$

$-0.60$

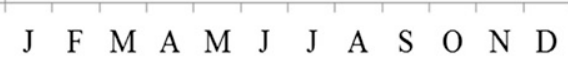

(d) $\mathrm{SM} \sim \mathrm{P}$
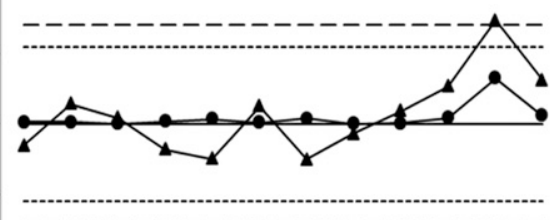

$\begin{array}{lllllllllllll}\text { J } & F & M & A & M & J & J & A & S & O & N & D\end{array}$

(f) $\mathrm{SF} \sim \mathrm{P}$
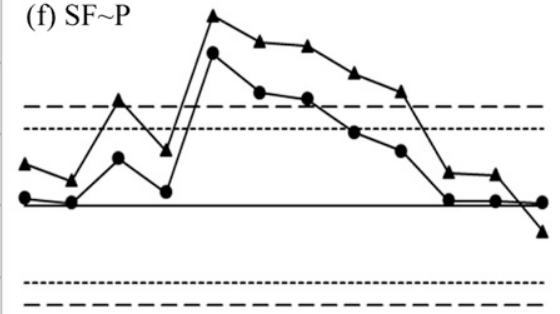

FIG. 5. (a)-(g) Coefficients of correlation $\left(R\right.$ and $\left.R^{2}\right)$ between the interannual variations of monthly hydrological and climate variables during 1974-2010. Note that $\operatorname{Rc}(0.32)$ and $\operatorname{Rf}(0.42)$ were $R$ respectively at the 0.05 and 0.01 significance level of two-tailed $t$ tests during 1974-2010. The meanings of $T, P, \mathrm{ET}, \mathrm{SF}$, and SM here as well as in Figs. 6-9 refer to Fig. 4.

annual evapotranspiration $(80.9 \mathrm{~mm})$ the percentages of the four seasons accounted for $2.4 \%, 67.3 \%, 20.1 \%$, and $0.2 \%$, respectively.

The simulated average annual streamflow (SF) was roughly $124.6 \mathrm{~mm}$ during $1974-2010$. The interannual variation of streamflow was relatively small with the variation coefficient $(\mathrm{Cv})$ of 0.3 and the annual extreme value ratio of 2.7. With the application of the Global Water flow probe FP101, the measured streamflow of $12.2 \mathrm{~m}^{3} \mathrm{~s}^{-1}$ on 11 September 2010 was still within the 

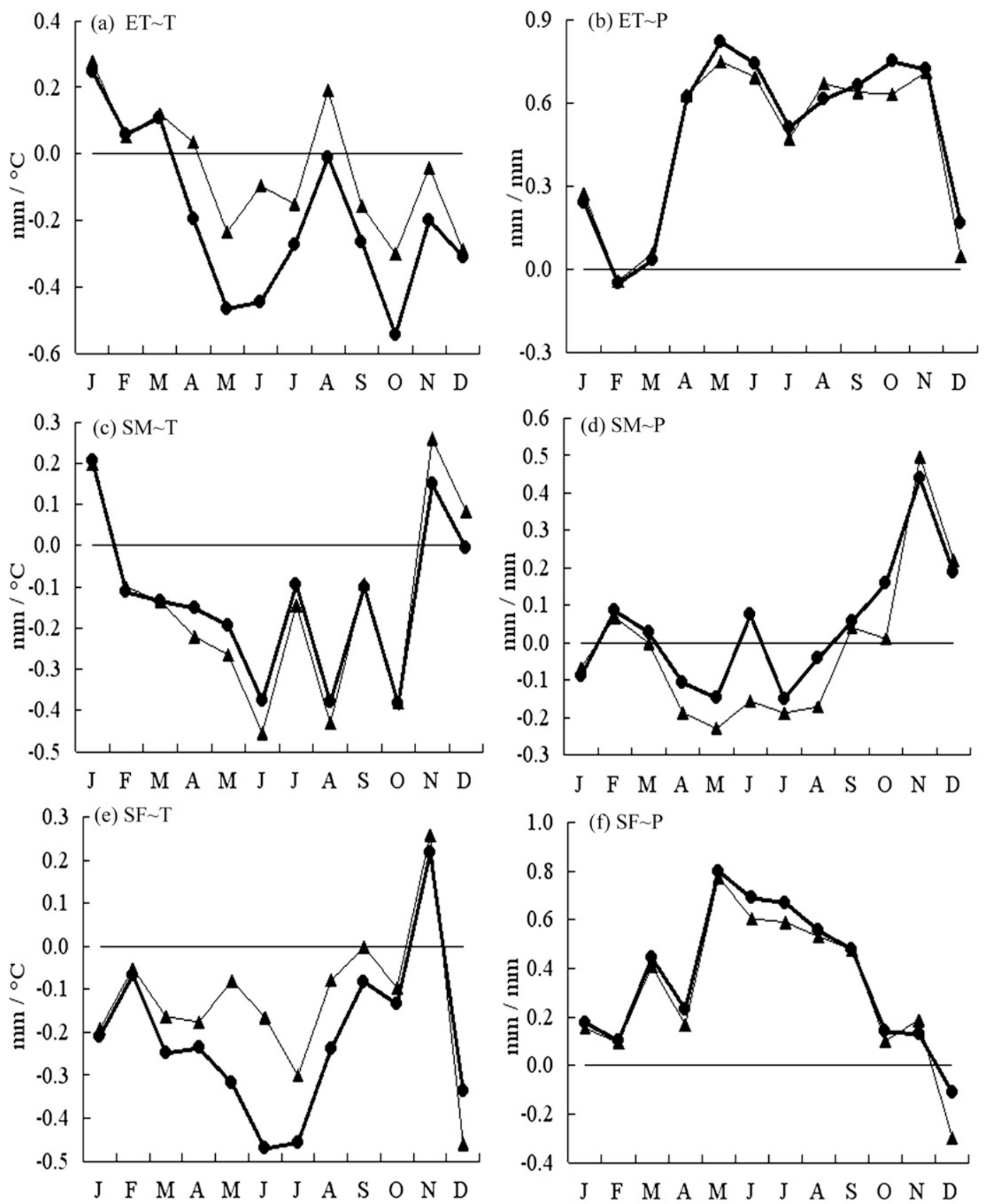

\section{$\rightarrow d S / d T$ or $d S / d P \rightarrow \partial S / \partial T$ or $\partial S / \partial P-0$}

FIG. 6. (a)-(f) Coefficients of simple and multiple regressions for interannual monthly hydrological variables against temperature and precipitation, respectively, during 1974-2010.

range of $7.5-29.9 \mathrm{~m}^{3} \mathrm{~s}^{-1}$ observed on the same day in 1983-95, which implied that the interannual variation of streamflow was moderate during the past 37 years. The streamflow simulated by SWAT was very close to the observed streamflow averaged over 1983-95, especially in seasonal patterns. The seasonal distribution of streamflow was also uneven during 1974-2010 (Fig. 4d). The streamflow in spring, summer, autumn, and winter accounted for $5.8 \%, 56.9 \%, 36.1 \%$, and $1.2 \%$ of the total annual streamflow, respectively. The snowmelt (SM) accounting for $4.0 \%$ of the annual streamflow had a maximum in April-May and a minimum in August-January (Fig. 4e). 

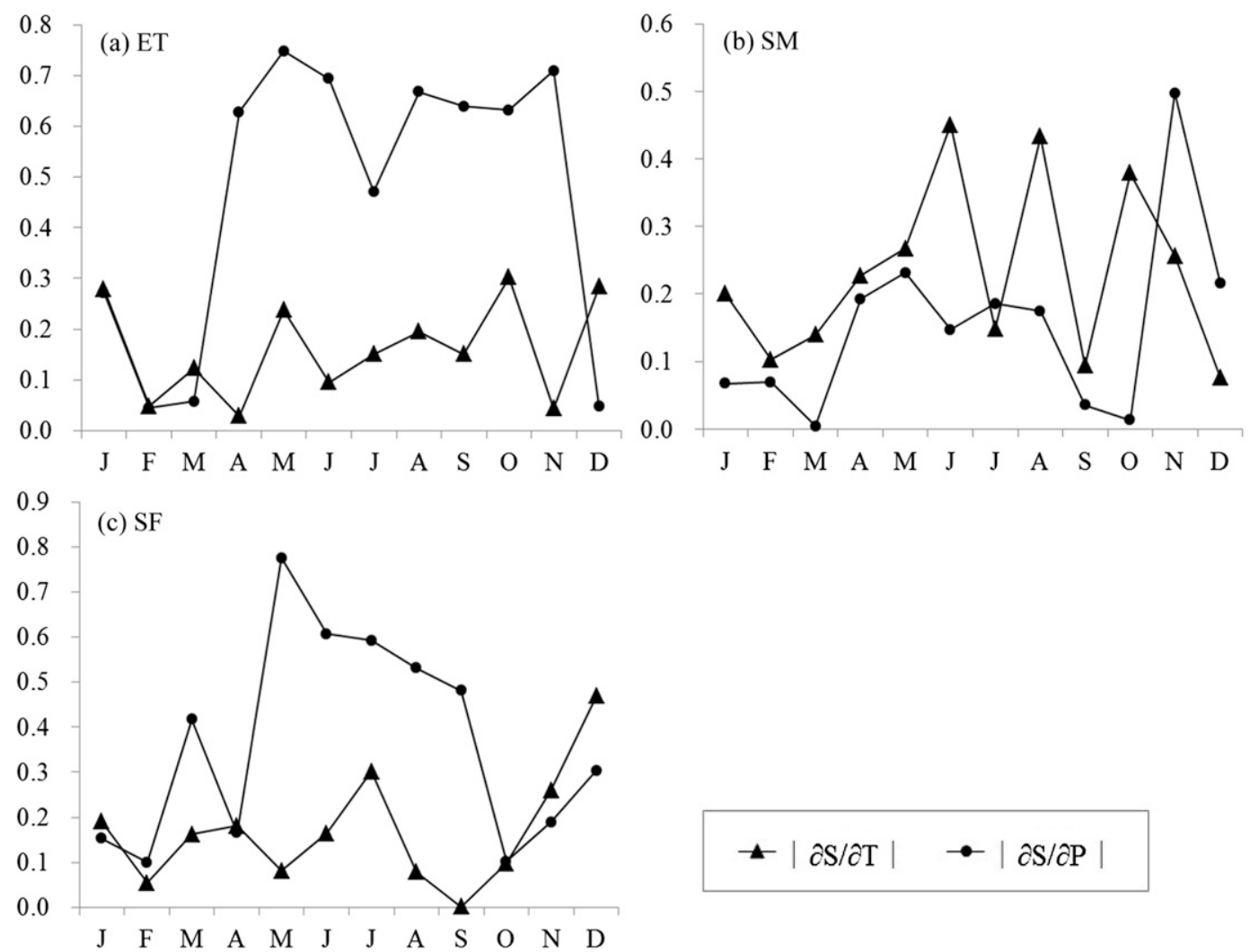

FIG. 7. (a)-(c) Absolute values of the multiple regression coefficients for interannual monthly hydrological variables against temperature and precipitation during 1974-2010.

\section{c. Responses of streamflow to climate change}

Correlations and regressions between the monthly hydrological variables (evapotranspiration, snowmelt, and streamflow) and climate variables (temperature and precipitation) were estimated to analyze the impacts of the interannual monthly averaged climate changes on the variations of streamflow in the same month during 1974-2010 (Figs. 5-8).

The correlation between evapotranspiration and temperature was positive in January-March but negative in April-December (Fig. 5a). Temperature was the major factor determining the interannual variation of evapotranspiration in December-March (Fig. 7a), and the contributions of temperature to the variation of evapotranspiration were more important than that of precipitation in the four months (Fig. 8a). On the contrary, precipitation was significant for the evapotranspiration variation in April-November (Fig. 7a), and its contributions to the interannual variation of evapotranspiration were more important than that of temperature (Fig. 8a). Evapotranspiration and precipitation were positively correlated with the coefficient of determination $\left(R^{2}\right)$ of $0.26-0.67$ in April-November
(Fig. 5b); the increase rates of evapotranspiration with precipitation were huge in the warm months (Fig. 6b). It is the precipitation dominating evapotranspiration variations and negative correlation between temperature and precipitation (Fig. $5 \mathrm{~g}$ ) that caused the negative correlation of evapotranspiration with temperature in April-November (Fig. 5a). Furthermore, there was a slight dip of the correlation between evapotranspiration and precipitation in July due to the large variation of precipitation (Fig. 4b).

Snowmelt and temperature variations revealed negative correlation in February-October but positive correlation in the other months (Fig. 5c); the change rates of snowmelt with temperature were also negative and large in February-October (Fig. 6c). Although temperature was a major factor influencing snowmelt variation in JanuaryJune and August-October (Fig. 7b), more rain and less snow with increasing temperature in the warm months resulted in the small contribution of the increasing temperature to the interannual variation of snowmelt. Hence, the interannual variation of snowmelt was also dominated by precipitation in April-September, whereas the warming temperature contributed much more to the interannual variations of snowmelt in January-March (Fig. 8b). 

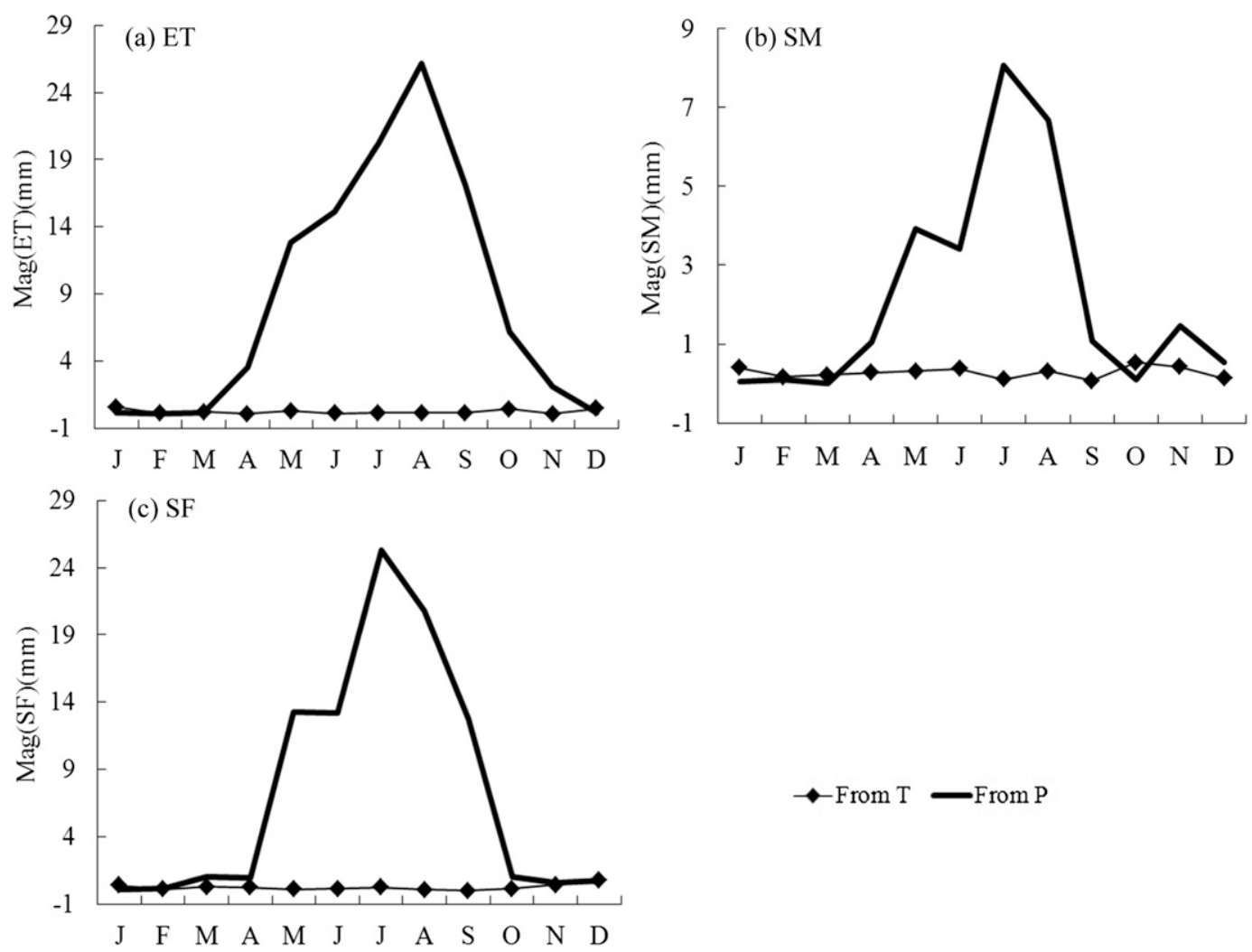

FIG. 8. (a)-(c) Magnitudes of interannual variations of monthly hydrological variables estimated by multiplying the multiple regression coefficients by the standard deviations of temperature or precipitation.

Streamflow had negative correlation with temperature in all months except November (Fig. 5e), whereas it had strong positive correlation with precipitation in May-September with an $R^{2}$ of $0.23-0.64$ (Fig. 5f). The streamflow had the largest decrease rate (with temperature) in early summer (Fig. 6e) and its increase rate (with precipitation) was maximum in late spring-early summer (Fig. 6f). Warming temperature was the predominant factor of the interannual variation of streamflow in November-January; both temperature and precipitation changes were important for the streamflow variation in April and October, whereas precipitation played a pivotal role in the streamflow changes for the other months (Fig. 7c). Consequently, the contribution of temperature variation was slightly larger than that of precipitation to the interannual variation of streamflow in winter, whereas the variation of precipitation was much more important in the other seasons (Fig. 8c).

\section{d. Changes of streamflow under climate scenarios}

The changes of monthly streamflow between the 20-yr averages of future (2030-49) and current periods (198099) indicate that the monthly streamflow will change consistently with precipitation while being negatively correlated with temperature, and the largest changes of streamflow occur in August (Fig. 9a). The monthly streamflow in January-March was much more sensitive to impacts of climate changes than in all other months (Fig. 9d), although the responses of the annual streamflow to climate change were relatively moderate in this alpine watershed. The monthly evapotranspiration, which was more susceptible to the climate change in December-April (Fig. 9e), has a positive correlation with both temperature and precipitation (Fig. 9b), for which the evapotranspiration will change most remarkably in July. In addition, the monthly snowmelt in summer and autumn is highly affected by climate change (Fig. 9f) and exhibits a declining tendency especially in April-June (Fig. 9c) due to the negative impact of warming temperature on the snowmelt variation.

With the projected climatic scenario (i.e., the first type of climatic scenarios), the streamflow decreases in all months except August, evapotranspiration increases in all months, and snowmelt shows small changes (Figs. 9a-c). Compared to the period 1980-99, the annual streamflow in 2030-49 will decrease by $1.62 \%$ and evapotranspiration and snowmelt will increase by $5.85 \%$ and $0.04 \%$, respectively. Correspondingly, the seasonal streamflow will 

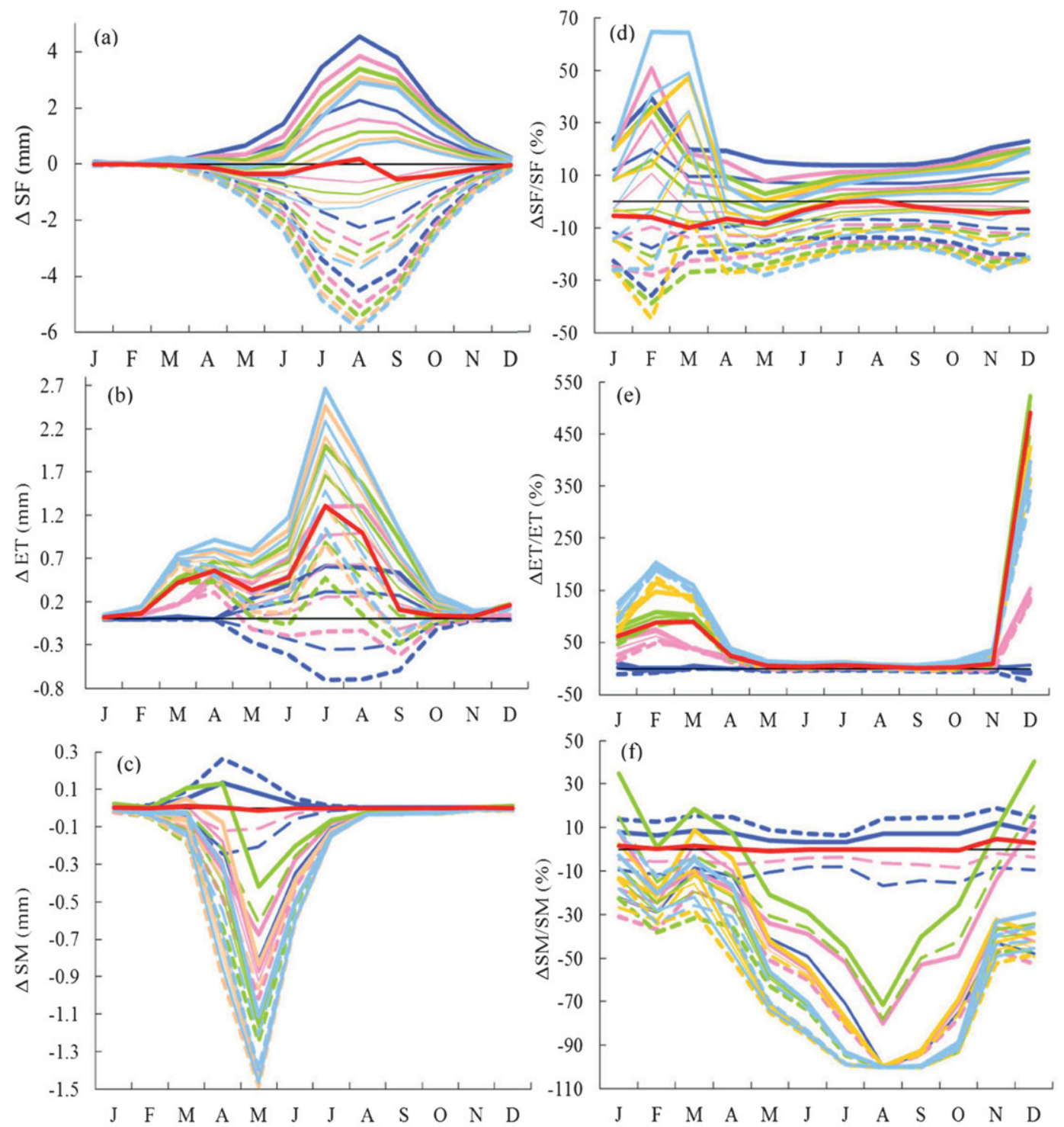

\begin{tabular}{|c|c|c|c|c|}
\hline first type & $\leadsto\left(\Delta \mathrm{T}=+0^{\circ} \quad \mathrm{C}, \Delta \mathrm{P}=-10 \%\right)$ & $--\left(\Delta \mathrm{T}=+0^{\circ} \quad \mathrm{C}, \Delta \mathrm{P}=-5 \%\right)$ & $-\left(\Delta \mathrm{T}=+0^{\circ} \quad \mathrm{C}, \Delta \mathrm{P}=+5 \%\right)$ & $-\left(\Delta \mathrm{T}=\div 0^{\circ} \quad \mathrm{C}, \Delta \mathrm{V}\right.$ \\
\hline$\cdots\left(\Delta \mathrm{T}=\div 1^{\circ} \quad \mathrm{C}, \Delta \mathrm{P}=-10 \%\right)$ & $-\left(\Delta \mathrm{T}=+1^{\circ} \quad \mathrm{C}, \Delta \mathrm{P}=-5 \%\right)$ & $\left(\Delta \mathrm{T}=+1^{\circ} \quad \mathrm{C}, \Delta \mathrm{P}=+0 \%\right)$ & $\left(\Delta \mathrm{T}=+1^{\circ} \quad \mathrm{C}, \Delta \mathrm{P}=+5 \%\right)$ & $\left(\Delta \mathrm{T}=\div 1^{\circ} \mathrm{C}, \Delta \mathrm{V}\right.$ \\
\hline$\div 2^{\circ} \mathrm{C}$, & $--\left(\Delta \mathrm{T}=+2^{\circ} \mathrm{C}\right.$ & $\left(\Delta \mathrm{T}=+2^{\circ} \mathrm{C}\right.$ & $\left(\Delta \mathrm{T}=+2^{\circ} \mathrm{C}\right.$ & $\div 2^{\circ} \mathrm{C}$ \\
\hline$\left(\Delta \mathrm{T}=\div 3^{\circ} \quad \mathrm{C}, \Delta \mathrm{P}=-10 \%\right)$ & $-\left(\Delta \mathrm{T}=+3^{\circ} \quad \mathrm{C}, \Delta \mathrm{P}=-5 \%\right)$ & $\left(\Delta \mathrm{T}=+3^{\circ} \mathrm{C}\right.$ & $\left(\Delta \mathrm{T}=+3^{\circ} \mathrm{C}\right.$ & $=\div 3^{\circ} \mathrm{C}$ \\
\hline $\begin{array}{l}-\left(\Delta \mathrm{T}=\div 4^{\circ} \quad \mathrm{C}, \Delta \mathrm{P}=-10 \%\right) \\
-0\end{array}$ & $--\left(\Delta \mathrm{T}=+4^{\circ} \quad \mathrm{C}, \Delta \mathrm{P}=-5 \%\right)$ & $\left(\Delta \mathrm{T}=+4^{\circ} \quad \mathrm{C}, \Delta \mathrm{P}=+0 \%\right)$ & $\left(\Delta \mathrm{T}=+4^{\circ} \mathrm{C}, \Delta \mathrm{P}\right.$ & $\left(\Delta \mathrm{T}=\div 4^{\circ} \mathrm{C}, \Delta \mathrm{P}\right.$ \\
\hline
\end{tabular}

FIG. 9. Changes of monthly hydrological variables from the averages of current years (1980-99) to that of the future (2030-49): (a)-(c) the change magnitudes of streamflow (SF), evapotranspiration (ET), and snowmelt (SM), respectively, and (d)-(f) the corresponding percentage changes of SF, ET, and SM, respectively. The solid (dashed) lines are used for zero or positive (negative) $\Delta P$. The "first type" in the legend (red solid line) indicates the projected climatic scenarios.

decrease by $7.96 \%, 0.30 \%, 2.63 \%$, and $4.17 \%$ in spring, summer, autumn, and winter, respectively, while the evapotranspiration will increase in the four seasons by $15.75 \%, 5.29 \%, 1.05 \%$, and $173.05 \%$. Snowmelt will decrease by $0.24 \%$ in summer but increase by $0.03 \%, 1.08 \%$, and $1.05 \%$ in spring, autumn, and winter, respectively.
Comparing mean annual precipitation $(P)$ and streamflow (SF) of 20-yr observations (1980-99) with the presumptive scenario (2030-49; see section 2) we notice the following changes: keeping the annual mean temperature constant $\left(\Delta T \approx 0^{\circ} \mathrm{C}\right)$, a $10 \%$ monthly precipitation increase $(\Delta P / P \approx 10 \%)$ leads to a SWAT deduced 
streamflow growth sensitivity of $14.7 \%(\Delta \mathrm{SF} / \mathrm{SF} \approx 14.7 \%)$. Thus, the streamflow elasticity (Dooge 1992) with respect to precipitation change $\varepsilon_{1}(\mathrm{SF}, P)=(\Delta \mathrm{SF} / \mathrm{SF}) /(\Delta P / P) \approx$ 1.47 .

This result can be interpreted in terms of the rainfallrunoff chain of watersheds that is embedded in the Budyko (1974) framework of climatic zonality: $C=\exp (-D)$. Here the long-term mean runoff ratio $C=\mathrm{SF} / P \approx 0.58$ leads to a dryness ratio $D=\mathrm{PET} / P \sim 0.54$, which is based on the annual mean (1974-2010) SWAT-simulated streamflow $\mathrm{SF} \approx 124.6 \mathrm{~mm}$ and precipitation $P \approx$ $215.4 \mathrm{~mm}$. Thus the related streamflow efficiency can be derived analytically, $\varepsilon_{2}(\mathrm{SF}, P)=1+D \approx 1.54$. The small difference between $\varepsilon_{1}$ and $\varepsilon_{2}$ shows that SWAT means responding on climate change can be well interpreted in terms of the rainfall-runoff chain within the Budyko framework. Note that the SWATsimulated precipitation is smaller than the one observed at Langkazi weather station, which is due to the vertical gradient of precipitation (PLAPS) of $-62.6 \mathrm{~mm}(\mathrm{~km})^{-1}$ in the KRW.

\section{Summary and discussion}

The SWAT model evaluation demonstrated its applicability to simulate streamflow in the Kadongjia River watershed (KRW) as a poorly gauged watershed in southern Tibet, leading to the following results: (i) Annual streamflow was estimated to be roughly $124.6 \mathrm{~mm}$ with relatively small interannual variation and uneven seasonal distributions during 1974-2010. (ii) Snowmelt, which was mainly produced in April-May, accounted for $4.0 \%$ of the annual streamflow. (iii) Linkage between changing streamflow and climate variables indicated warming temperature to be slightly more important for the interannual variations of streamflow in winter whereas precipitation was much more significant in the other three seasons. (iv) Streamflow variations were more sensitive to climate changes in winter and spring according to the future streamflow changes projected under climatic scenarios based on SWAT.

Although SWAT provides streamflow and its response to climate changes in KRW, these simulations might be further enhanced by improving the accuracy of key parameters (e.g., soil albedo, snow areal coverage) and by assimilating spatially interpolated meteorological data in the simulation including remote sensing data. Moreover, it must be noticed that for quantifying the time lag effect of climatic change, the hydrological cycle-related climatic variables (e.g., humidity, solar radiation, wind speed, etc.) and soil moisture should also be considered more in future applications and analyses of the relationship between hydrological and climatic variables to explore the detailed physical mechanisms of the hydrological response to climatic change in KRW.

The successful verification of the SWAT-based streamflow simulation of Kadongjia River, which provides the largest inflow to Yamzhog Yumco, encouraged further applications to estimate the other inflow rivers of the whole Yamzhog Yumco basin and analyze their responses to climate change. This is the precondition to explore the total streamflow contribution to determine lake level changes. It is urgent to understand the predominant causes for the declining lake level of Yamzhog Yumco observed during the past decades and thus the responses of lake levels to future climate scenarios in further studies. This will provide a quantitative basis for the local government to take measures to mitigate the negative effects resulting from regional environmental changes on the survival and production of local herdsmen and farmers.

Acknowledgments. This study was supported by the National Natural Science Foundation of China (41171062), the National Basic Research Program of China (973 Program) (Grant 2012CB955403), and the Max-Planck-Gesellschaft. We thank the Jet Propulsion Laboratory (California Institute of Technology and NASA) for providing the ASTER GDEM data, the Data Center for Resources and Environment Science, Chinese Academy of Sciences for providing the land use and soil datasets, and the Climate Data Center of National Meteorological Information Center of China Meteorological Administration for providing surface observations. The anonymous reviewers are thanked for their constructive comments and suggestions that were helpful in improving the manuscript.

\section{REFERENCES}

Arnold, J. G., R. Srinivasan, R. S. Muttiah, and J. R. Williams, 1998: Large area hydrologic modeling and assessment. Part I: Model development. J. Amer. Water Resour. Assoc., 34, 73-89.

$-,-\longrightarrow,-$, and P. M. Allen, 1999: Continental scale simulation of the hydrologic balance. J. Amer. Water Resour. Assoc., 35, 1037-1051.

Bian, D., Z. Yang, L. Li, D. Chu, G. Zhuo, C. Bianba, Y. Zhaxi, and Y. Dong, 2006: The response of lake area change to climate variations in north Tibetan Plateau during last 30 years. Acta Geogr. Sin., 61, 510-518.

_ J. Du, J. Hu, C. Li, and L. Li, 2009: Response of the water level of the Yamzho Yumco to climate change during 19752006. J. Glaciol. Geocryol., 31, 404-409.

Bosch, N. S., J. D. Allan, D. M. Dolan, H. Han, and R. P. Richards, 2011: Application of the Soil and Water Assessment Tool for six watersheds of Lake Erie: Model parameterization and calibration. J. Great Lakes Res., 37, 263-271. 
Bouraoui, F., S. Benabdallah, A. Jrad, and G. Bidoglio, 2005: Application of the SWAT model on the Medjerda river basin (Tunisia). Phys. Chem. Earth, 30, 497-507.

Budyko, M. I., 1974: Climate and Life. Academic Press, 508 pp.

Chaplot, V., 2007: Water and soil resources response to rising levels of atmospheric $\mathrm{CO}_{2}$ concentration and to changes in precipitation and air temperature. J. Hydrol., 337, 159-171.

Che, T., X. Li, P. K. Mool, and J. C. Xu, 2005: Monitoring glaciers and associated glacial lakes on the east slopes of Mount Xixabangma from remote sensing images. J. Glaciol. Geocryol., 6 , 801-805.

Chen, G.-C., Z.-W. Huang, X.-F. Lu, and M. Peng, 2002: Characteristics of wetland and its conservation in the Qinghai Plateau. J. Glaciol. Geocryol., 24, 254-259.

Chen, X.-Q., P. Cui, Y. Li, Z. Yang, and Y.-Q. Qi, 2007: Changes in glacial lakes and glaciers of post-1986 in the Poiqu River basin, Nyalam, Xizang (Tibet). Geomorphology, 88, 298-311.

Chu, D., Q. Pu, D. Wang, C. Mima, Z. Laba, X. Zhang, and R. Sun, 2012a: Water level variations of Yamzho Yumco Lake in Tibet and the main driving forces. J. Mt. Res., 30, 239-247.

_ , P. Qiong, Z. Laba, L. Zhu, X. Zhang, C. Pubu, Y. Deji, and R. Sun, 2012b: Remote sensing analysis on lake area variations of Yamzho Yumco in Tibetan Plateau over the past 40 a. J. Lake Sci., 24, 494-502.

Collins, W. D., and Coauthors, 2006: The Community Climate System Model version 3 (CCSM3). J. Climate, 19, 2122-2143.

Ding, Y.-H., and Coauthors, 2007: China's national assessment report on climate change (I): Climate change in China and the future trend. Adv. Climate Change Res., 3 (Suppl.), 1-5.

Ding, Y.-J., S. Liu, J. Li, and D. H. Shangguan, 2006: The retreat of glaciers in response to recent climate warming in western China. Ann. Glaciol., 43, 97-105.

Dooge, J. C. I., 1992: Sensitivity of runoff to climate change: A Hortonian approach. Bull. Amer. Meteor. Soc., 73, 2013-2024.

Ezekiel, M., and K. A. Fox, 1959: Methods of Correlation and Regression Analysis: Linear and Curvilinear. 3rd ed. John Wiley, $548 \mathrm{pp}$.

Feyen, L., R. Vázquez, K. Christiaens, O. Sels, and J. Feyen, 2000: Application of a distributed physically-based hydrological model to a medium size catchment. Hydrol. Earth Syst. Sci., 4, 47-63.

Ficklin, D. L., Y. Z. Luo, E. Luedeling, and M. H. Zhang, 2009: Climate change sensitivity assessment of a highly agricultural watershed using SWAT. J. Hydrol., 374, 16-29.

Fontaine, T. A., J. F. Klassen, T. S. Cruickshank, and R. H. Hotchkiss, 2001: Hydrological response to climate change in the Black Hills of South Dakota, USA. Hydrol. Sci. J., 46, 27-40.

, T. S. Cruickshank, J. G. Arnold, and R. H. Hotchkiss, 2002: Development of a snowfall-snowmelt routine for mountainous terrain for the soil water assessment tool (SWAT). J. Hydrol., 262, 209-223.

Gao, J., L. D. Tian, Y. Q. Liu, and T. L. Gong, 2009: Oxygen isotope variation in the water cycle of the Yamzho Lake Basin in southern Tibetan Plateau. Chin. Sci. Bull., 54, 2758-2765.

Ghan, S. J., and T. Shippert, 2006: Physically based global downscaling: Climate change projections for a full century. J. Climate, 19, 1589-1604.

Guan, Z.-H., and Coauthors, 1984: Rivers and Lakes of Tibet. Science Press, 238 pp.

Gupta, H. V., S. Sorooshian, and P. O. Yapo, 1998: Toward improved calibration of hydrologic models: Multiple and noncommensurable measures of information. Water Resour. Res., 34, 751-763.
Jürgen, S., C. A. Karim, S. Raghavan, and Y. Hong, 2008: Estimation of freshwater availability in the West African sub-continent using the SWAT hydrologic model. J. Hydrol., 352, 30-49.

Kang, S., F. Chen, Q. Ye, Z. Jing, D. Qin, and J. Ren, 2007: Glacier retreating dramatically on the Mt. Nyainqêntanglha during the last 40 years. J. Glaciol. Geocryol., 29, 869-873.

— , Y. Xu, Q. You, W.-A. Flügel, N. Pepin, and T. Yao, 2010: Review of climate and cryospheric change in the Tibetan Plateau. Environ. Res. Lett., 5, 015101, doi:10.1088/1748-9326/ 5/1/015101

Liu, R., and Y. Liu, 2008: Area changes of Lake Qinghai in the latest 20 years based on remote sensing study. J. Lake Sci., 20, 135-138.

Liu, T. C., 1995: Changes of Yamzho Lake water stage in Xizang. Acta Geogr. Sin., 15, 55-62.

Liu, X., and B. Chen, 2000: Climatic warming in the Tibetan Plateau during recent decades. Int. J. Climatol., 20, 1729-1742.

, Z.-Y. Yin, X. Shao, and N. Qin, 2006: Temporal trends and variability of daily maximum and minimum, extreme temperature events, and growing season length over the eastern and central Tibetan Plateau during 1961-2003. J. Geophys. Res., 111, D19109, doi:10.1029/2005JD006915.

— Z Z. Cheng, and R. Zhang, 2009: The A1B scenario projection for climate change over the Tibetan Plateau in the next 30-50 years. Plateau Meteor., 28, 475-484.

Lu, A.-X., T.-D. Yao, L.-H. Wang, S.-Y. Liu, and Z.-L. Guo, 2005: Study on the fluctuations of typical glaciers and lakes in the Tibetan Plateau using remote sensing. J. Glaciol. Geocryol., 27, 783-792.

Lu, E., E. S. Takle, and J. Manoj, 2009: The relationships between climatic and hydrological changes in the Upper Mississippi river basin: A SWAT and multi-GCM study. J. Hydrometeor., 11, 437-451.

Luosang, L., 2005: Utilization and protection of water resources in the Qinghai-Tibet Plateau. Resour. Sci., 27, 23-27.

Moriasi, D. N., J. G. Arnold, M. W. Van Liew, R. L. Bingner, R. D. Harmel, and T. L. Veith, 2007: Model evaluation guidelines for systematic quantification of accuracy in watershed simulations. Trans. ASABE, 50, 885-900.

Nakicenovic, N., and Coauthors, 2000: Special Report on Emissions Scenarios. Cambridge University Press, 599 pp.

National Soil Survey Office, 1996: Soil Species of China. China Agriculture Press, 730 pp.

Neitsch, S. L., J. G. Arnold, J. R. Kiniry, J. R. Williams, and K. W. King, 2001: Soil and Water Assessment Tool theoretical documentation, version 2000. [Available online at http://swatmodel. tamu.edu/documentation/.]

,,,--- R. Srinivasan, and J. R. Williams, 2002: Soil and Water Assessment Tool: User's manual, version 2000. [Available online at http://swatmodel.tamu.edu/documentation/.]

$\_,-, \ldots$, and J. R. Williams, 2005: Soil and Water Assessment Tool theoretical documentation, version 2005. [Available online at http://swatmodel.tamu.edu/documentation/.]

Pisinaras, V., C. Petalas, G. D. Gikas, A. Gemitzi, and V. A. Tsihrintzis, 2010: Hydrological and water quality modeling in a medium-sized basin using the Soil and Water Assessment Tool (SWAT). Desalination, 250, 274-286.

Qiao, C., J. C. Luo, Y. W. Sheng, Z. F. Shen, J. L. Li, and L. J. Gao, 2010: Analysis on lake changes since ancient and modern ages using remote sensing in Dagze Co, Tibetan Plateau. J. Lake Sci., 22, 98-102.

Refsgaard, J. C., 1997: Parameterisation, calibration and validation of distributed hydrological models. J. Hydrol., 198, 69-97. 
Ritchie, J. T., 1972: A model for predicting evaporation from a row crop with incomplete cover. Water Resour. Res., 8, 1204-1213.

Santhi, C., J. G. Arnold, J. R. Williams, W. A. Dugas, R. Srinivasan, and L. M. Hauck, 2001: Validation of the SWAT model on a large river basin with point and nonpoint sources. J. Amer. Water Resour. Assoc., 37, 1169-1188.

Saxton, K. E., and P. H. Willey, 2005: Soil water characteristics hydraulic properties calculator. [Available online at http:// hydrolab.arsusda.gov/soilwater/Index.htm.]

— W. W. Rawls, J. S. Romberger, and R. I. Papendick, 1986: Estimating generalized soil-water characteristics from texture. Soil Sci. Soc. Amer. J., 50, 1031-1036.

Shangguan, D., S. Liu, Y. Ding, Y. Zhang, E. Du, and Z. Wu, 2008: Thinning and retreat of Xiao Dongkemadi glacier, Tibetan Plateau, since 1993. J. Glaciol., 54, 949-951.

Shao, Z. G., and Coauthors, 2007: Characteristics of the change of major lakes on the Qinghai-Tibet Plateau in the last 25 years. Geol. Bull. China, 26, 1633-1645.

Shen, D. J., and C. Y. Chen, 1996: Water resources of the QinghaiXizang Plateau and its exploitation. J. Nat. Res., 11, 8-14.

Shi, Y. F., and J. W. Ren, 1990: Glacier recession and lake shrinkage indicating a climatic warming and drying trend in central Asia. Ann. Glaciol., 14, 261-265.

Sivapalan, M., and Coauthors, 2003: IAHS decade on predictions in ungauged basins (PUB), 2003-2012: Shaping an exciting future for the hydrological sciences. Hydrol. Sci. J., 48, 857880.

Srinivasan, R., J. G. Arnold, and C. A. Jones, 1998: Hydrologic modeling of the United States with the Soil and Water Assessment Tool. Int. J. Water Resour. Dev., 4, 315-325.

- $\longrightarrow$ X. Zhang, and J. Arnold, 2010: SWAT ungauged: Hydrological budget and crop yield predictions in the Upper Mississippi River Basin. Trans. ASABE, 53, 1533-1546.

Stonefelt, M. D., T. A. Fontaine, and R. H. Hotchkiss, 2000: Impacts of climate change on water yield in the Upper Wind River basin. J. Amer. Water Resour. Assoc., 36, 321-336.

Sun, R., X. Q. Zhang, and Y. H. Wu, 2012: Major ion chemistry of waters and its possible controlling factors in the Yamzhog Yumco Basin, South Tibet. J. Lake Sci., 24, 619-627.

Tian, Y., X. Q. Zhang, and R. Sun, 2012: Extracting alpine lake information based on multi-source and multi-temporal satellite images and its uncertainty analysis-A case study in Yamzhog Yumco Basin, South Tibet. J. Glaciol. Geocryol., 34, 563-572.

Wang, B., Q. Bao, B. Hoskins, G. X. Wu, and Y. M. Liu, 2008: Tibetan Plateau warming and precipitation changes in East Asia. Geophys. Res. Lett., 35, L14702, doi:10.1029/2008GL034330.

Wang, X., S. Liu, X. Yao, W. Guo, P. Yu, and J. Xu, 2010: Glacier lake investigation and inventory in the Chinese Himalayas based on the remote sensing data. Acta Geogr. Sin., 65, 29-36.
White, K. L., and I. Chaubey, 2005: Sensitivity analysis, calibration, and validations for a multisite and multivariable SWAT model. J. Amer. Water Resour. Assoc., 41, 1077-1089.

Wu, K. S., and C. A. Johnston, 2007: Hydrologic response to climatic variability in a Great Lakes watershed: A case study with the SWAT model. J. Hydrol., 337, 187-199.

Wu, Y., and L. Zhu, 2008: The response of lake-glacier variations to climate change in Nam Co catchment, central Tibetan Plateau, during 1970-2000. J. Geogr. Sci., 18, 177-189.

$\mathrm{Xu}, \mathrm{B}$., and Coauthors, 2009: Black soot and the survival of Tibetan glaciers. Proc. Natl. Acad. Sci. USA, 106, 22 114-22 118.

$\mathrm{Xu}, \mathrm{C} ., 2003$ : Testing the transferability of regression equations derived from small sub-catchments to large area in central Sweden. Hydrol. Earth Syst. Sci., 7, 317-324.

Xu, Y., Y. H. Ding, and D. L. Li, 2003: Climatic change over Qinghai and Xizang in 21st century. Plateau Meteor., 22, 451-457.

Xu, Z. X., T. L. Gong, and J. Y. Li, 2008: Decadal trend of climate in the Tibetan Plateau-Regional temperature and precipitation. Hydrol. Proc., 22, 3056-3065.

Yao, T., Z. Li, W. Yang, X. Guo, L. Zhu, S. Kang, Y. Wu, and W. Yu, 2010: Glacial distribution and mass balance in the Yarlung Zangbo River and its influence on lakes. Chin. Sci. Bull., 55, 2072-2078.

—_, Y. Wang, S. Liu, J. Pu, Y. Shen, and A. Lu, 2004: Recent glacial retreat in High Asia in China and its impact on water resource in northwest China. Sci. China, 47D, 1065-1075.

Ye, Q., L. Zhu, H. Zheng, R. Naruse, X. Zhang, and S. Kang, 2007: Glacier and lake variation in the Yamzhog Yumco basin, southern Tibetan Plateau, from 1980 to 2000 using remotesensing and GIS technologies. J. Glaciol., 53, 673-676.

_ T. Yao, H. Zheng, and X. Zhang, 2008: Glacier and lake covariations and their responses to climate change in the Mapam Yumco Basin on Tibet. Geogr. Res., 27, 1178-1190.

You, Q., S. Kang, E. Aguilar, and Y. Yan, 2008: Changes in daily climate extremes in the eastern and central Tibetan Plateau during 1961-2005. J. Geophys. Res., 113, D07101, doi:10.1029/ 2007JD009389.

Zhang, G., H. Xie, S. Kang, D. Yi, and S. Ackley, 2011: Monitoring lake level changes on the Tibetan Plateau using ICESat altimetry data (2003-2009). Remote Sens. Environ., 115, 1733-1742.

Zhang, X., R. Srinivasan, and F. Hao, 2007: Predicting hydrologic response to climate change in the Luohe River basin using the SWAT model. Trans. ASABE, 50, 901-910.

,$- \ldots$, B. Debele, and F. Hao, 2008: Runoff simulation of the headwaters of the Yellow River using the SWAT model with three snowmelt algorithms. J. Amer. Water Resour. Assoc., 44, 48-61.

Zhu, L. P., X. Zhen, J. Wang, H. Lü, M. Xie, H. Kitagawa, and G. Possnert, 2009: A 30,000-year record of environmental changes inferred from Lake Chen Co, southern Tibet. $J$. Paleolimnol., 42, 343-358. 